Original Paper http://ajol.info/index.php/ijbcs $\quad$ http://indexmedicus.afro.who.int

\title{
Petrogenesis modeling of the alkaline volcanism of Ngaoundéré (Adamawa plateau, Cameroon, Central Africa)
}

\author{
Oumarou F. NKOUANDOU ${ }^{1 *}$, Aminatou F. MEFIRE ${ }^{1}$ and Bernard DERUELLE ${ }^{2}$ \\ ${ }^{I}$ Département des Sciences de la Terre, Faculté des Sciences, Université de Ngaoundéré B.P. 454, \\ Ngaoundéré, Cameroun. \\ ${ }^{2}$ Laboratoire de Magmatologie et Géochimie Inorganique et Expérimentale, Université Pierre et Marie Curie, \\ 4, place Jussieu, 75252 Paris, cedex 05, France. \\ *Corresponding author; E-mail: ofaarouk@yahoo.fr
}

\section{ACKNOWLEDGMENTS}

Warm thank to 'Agence Universitaire de la Francophonie (AUF)' through 'Projet de soutien aux équipes de recherche $n^{\circ} 51110 S U 201$ ' for supplement analyses.

\begin{abstract}
New insights on geochemistry of the alkaline volcanism of Ngaoundéré in Adamawa plateau enable the petrogenesis modelling of Ngaoundéré Miocene lava series. Mass-balance crystal fractionation, closed-system Assimilation, Fractional Crystallization (AFC) and partial melting rate modeling attempted for Ngaoundéré volcanism are re-examined. Inductively Couple Plasma-Mass Spectrometry (ICP-MS) and Inductively Couple Plasma Atomic Emission Spectroscopy (ICP-AES) analyses show that lavas are microlitic porphyritic textures. Decrease of major element $\left(\mathrm{MgO}, \mathrm{Fe}_{2} \mathrm{O}_{3}, \mathrm{TiO}_{2}, \mathrm{CaO}\right)$ with increasing $\mathrm{SiO}_{2}$ contents results from fractionation of olivine, clinopyroxene and Fe-Ti-oxides in the parental basaltic magma. Similarly, for felsic magma, decrease in $\mathrm{Al}_{2} \mathrm{O}_{3}, \mathrm{Na}_{2} \mathrm{O}$ and $\mathrm{K}_{2} \mathrm{O}$ contents depends upon feldspar fractionation and decrease in $\mathrm{P}_{2} \mathrm{O}_{5}$ from apatite fractionation, thus underline a typical feature of alkaline basaltic lavas of Ngaoundéré volcanism. The results evidence the differentiation by fractional crystallization process. Parental magmas of Ngaoundéré volcanism have undergone a low partial melting rate (2 to $3 \%)$ of the heterogeneous mantle source.

(c) 2016 International Formulae Group. All rights reserved.
\end{abstract}

Keywords: Major and trace elements, fractional crystallization, partial melting, modeling, Ngaoundéré volcanism, Adamawa plateau.

\section{INTRODUCTION}

The Adamawa plateau is a horst limited North and South by large $\mathrm{N} 70^{\circ} \mathrm{E}$ striking-slip faults (Adamawa and DjérémMbéré faults respectively). This horst consists of Precambrian metamorphic rocks intruded by Paleozoic granite-syenite plutons (Ganwa et al., 2011). The $\mathrm{N} 70^{\circ} \mathrm{E}$ faults belong to the
Central Africa Shear Zone (Figure 1) which extends from the Atlantic Ocean to Central Africa (Nnange et al., 2000) and they are active since Cretaceous. Transform faults of the Atlantic Ocean crust (Toteu et al., 2004) are parallel to the N70 trend which is distinct from the $\mathrm{N} 30^{\circ} \mathrm{E}$ trend of the Cameroon Volcanic Line (Déruelle et al., 2007). Three 
volcanic units are broadly distinguished in the Adamawa region (Nkouandou et al., 2008): The (1) Cretaceous-Paleogene lower black series mostly consists in basaltic lava flows completely modified by lateritic alteration, clinopyroxene phenocrysts being sometimes preserved inside a reddish groundmass. The (2) white intermediate series is of Miocene age and consists in numerous trachytes and phonolites plugs mostly North and East of Ngaoundéré (Nkouandou et al., 2008). The (3) upper black series consists in PlioceneQuaternary basaltic strombolian cones and their associated lava flows mostly South of Ngaoundéré. In the North and East of Ngaoundéré, basaltic lava flows of the upper series have been emitted by numerous centers now observed as necks (Voglar, Pofreh, Bijoro). Despite the present southwards slope of the plateau, most of the lavas flowed radially around the centers. Previous studies on the Miocene volcanic of Ngaoundéré area (Nkouandou et al., 2008, 2010; Fagny et al., 2012; Mbowou et al., 2013) have constrained the main petrogenesis processes at the origin of Adamawa plateau volcanism. This work presents the petrogenetic models of Miocene volcanism from the North and East of Ngaoundéré, using the unpublished supplement data of basaltic and newly analysed phonolitic and trachytic rocks.

\section{MATERIALS AND METHODS Geological setting}

Geological map of the volcanism of Ngaoundéré is presented in Figure 2. The lavas are of basaltic and intermediate composition. Phonotephrite-benmoreite breccias, phonolite and trachyte flows and plugs, and recent tiny outpourings of basaltic lavas are also present. Three units of basaltic lava flows (lower (LFU), middle (MFU) and upper (UFU) flow units) are distinguished by their stratigraphic and surface-weathering characteristics. The thickness of the lithosphere beneath the Adamawa plateau is reduced to $80 \mathrm{~km}$ and the density of the underlying asthenosphere is abnomalously low as deduced from gravity (negative
Bouguer anomalies, Nnange et al., 2001) and seismic (Nnange et al., 2000) data. Underline mantle of Adamawa plateau mainly composed of lherzolite peridotite (Nkouandou et al., 2011, 2015). The continental crust of the Adamawa plateau is thin $(20 \mathrm{~km})$ and consists of Precambrian metamorphic rocks intruded by granitoids of Pan-African age (610-652 \pm $54 \mathrm{Ma}$ ) or older $(926 \pm 12 \mathrm{Ma})$ (Tchameni et al., 2006; Ganwa et al., 2011b, 2016), crosscut by dolerites of continental tholeiite composition (Nkouandou et al., 2015) and partially covered by volcanic rocks.

\section{Materials and analytical method}

12 major and trace element analyses of lavas were determined using representative samples by ICP-AES and ICP-MS at the Acmel laboratory of Vancouver, Canada (Table 1). The prepared samples were mixed with $\mathrm{LiBO}_{2} / \mathrm{Li}_{2} \mathrm{~B}_{4} \mathrm{O}$ flux. Crucibles were fused in a furnace. The cooled bead were dissolved in ACS-grade nitric acid and analyzed by ICP and/or ICP-MS. Loss on ignition (LOI) is determined by igniting a sample split then measuring the weight loss. Data corrections were made using a PAP method correction of Pouchou and Pichoir (1991).

\section{RESULTS}

\section{Major element distribution}

Lavas are named (Figure 3) according to IUGS classification after Le Maitre (2002). There are basalt, phonotephrite, trachyte and phonolite. Trachytes containing nepheline phase are considering as phonolite. Major element distribution is illustrated in Figure 4. Contents in $\mathrm{TiO}_{2}, \mathrm{Fe}_{2} \mathrm{O}_{3}, \mathrm{MgO}, \mathrm{CaO}$ and $\mathrm{P} 2 \mathrm{O} 5$ decrease while contents in $\mathrm{Al}_{2} \mathrm{O}_{3}$, $\mathrm{Na}_{2} \mathrm{O}$ and $\mathrm{K}_{2} \mathrm{O}$ increase from basaltic to felsic lavas. Particularly, $\mathrm{Al}_{2} \mathrm{O}_{3}$ contents increase from basaltic lavas to phonolites then decrease till trachytes. $\mathrm{P}_{2} \mathrm{O}_{5}$ contents increase in basalts and phonotephrite then strongly decrease to very low values in felsic lavas, nearby the detection limit. 


\section{Trace elements distribution}

In spiderdiagrams, basaltic lava patterns are similar to typical Ocean Island Basalts (OIB) patterns with positive Nb-Ta, $\mathrm{Ba}$ and negative $\mathrm{K}$ and $\mathrm{Pb}$ anomalies. Slightly negative $\mathrm{Ti}$ anomaly characterizes phonotephrite (Figure 5A). Felsic lava patterns are characterized by positive anomalies in $\mathrm{Rb}, \mathrm{Th}, \mathrm{Nb}, \mathrm{Ta}, \mathrm{Hf}$ and $\mathrm{Zr}$ and marked negative anomalies in $\mathrm{Ba}, \mathrm{P}, \mathrm{Sr}$ and $\mathrm{Ti}$, and slight negative anomaly in $\mathrm{K}$. Phonolites are depleted in Rare Earth Elements (REE). Trachytes have more pronounced positive and negative anomalies. There is no Eu-anomaly (except for trachytes).As a typical feature of alkaline basaltic lavas worldwide, REE normalized patterns have a regular decrease from La to $\mathrm{Lu}$ and do not have europium anomaly (Figure 5B). Felsic lavas are characterized by spoon-shaped patterns particularly for phonolites NG2F (dashed pattern) and NG22. Trachytes have relatively high REE contents and a noteworthy $\mathrm{Eu}$ anomaly $\left(\mathrm{Eu} / \mathrm{Eu}^{*}=\right.$ EuN $\left./ \sqrt{ } \mathrm{SmN}^{*} \mathrm{GdN}\right)$, especially for phonolite NG16 (Figure 5B), as low as 0.7.

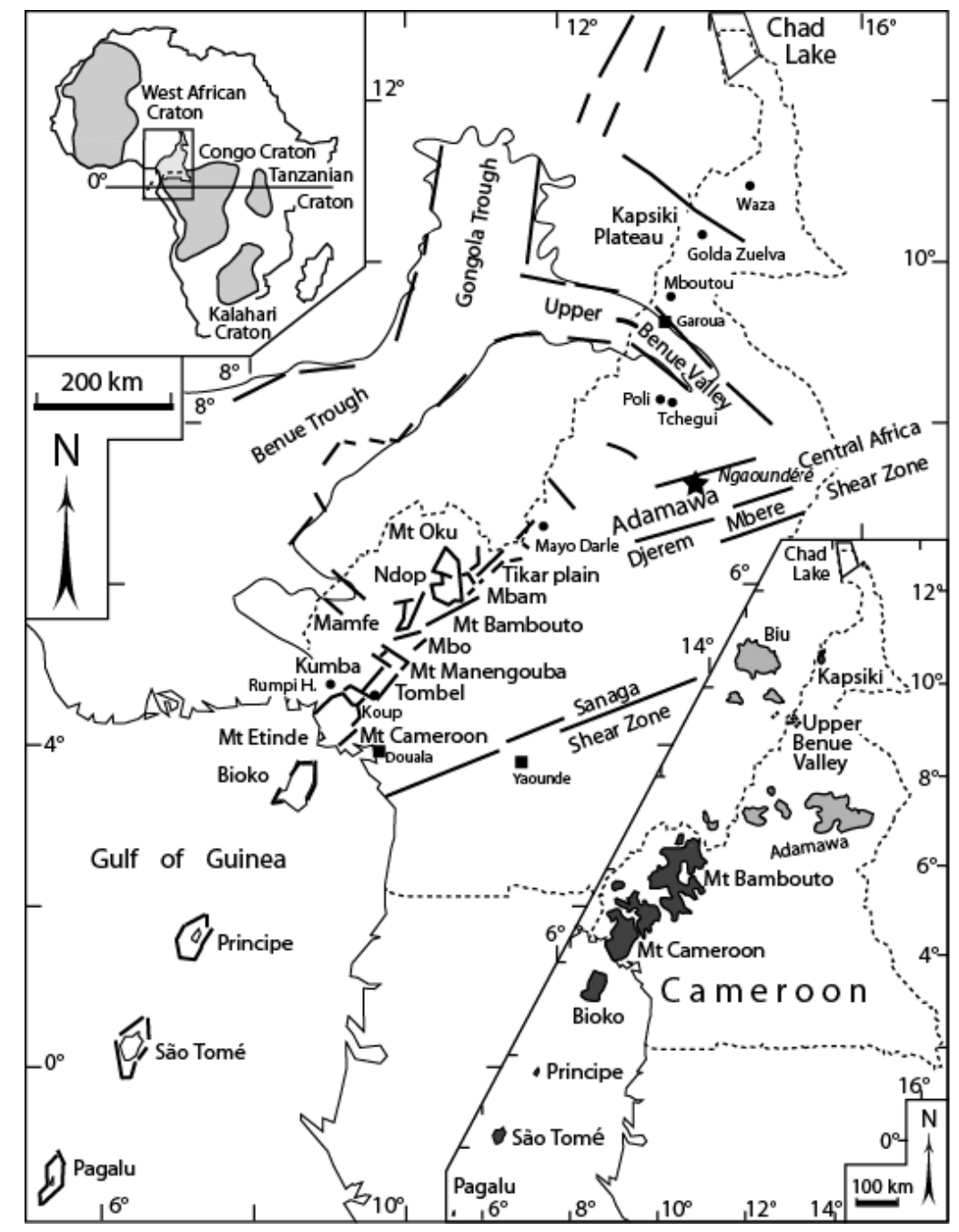

Figure 1: Location of the studied area (black star) in the Adamawa plateau. The main volcanic and plutonic complexes of the Cameroon volcanic line (names in italic) and lower inset are taken from Déruelle et al. (1991). African cratons are after Kampunzu and Popoff (1991). 


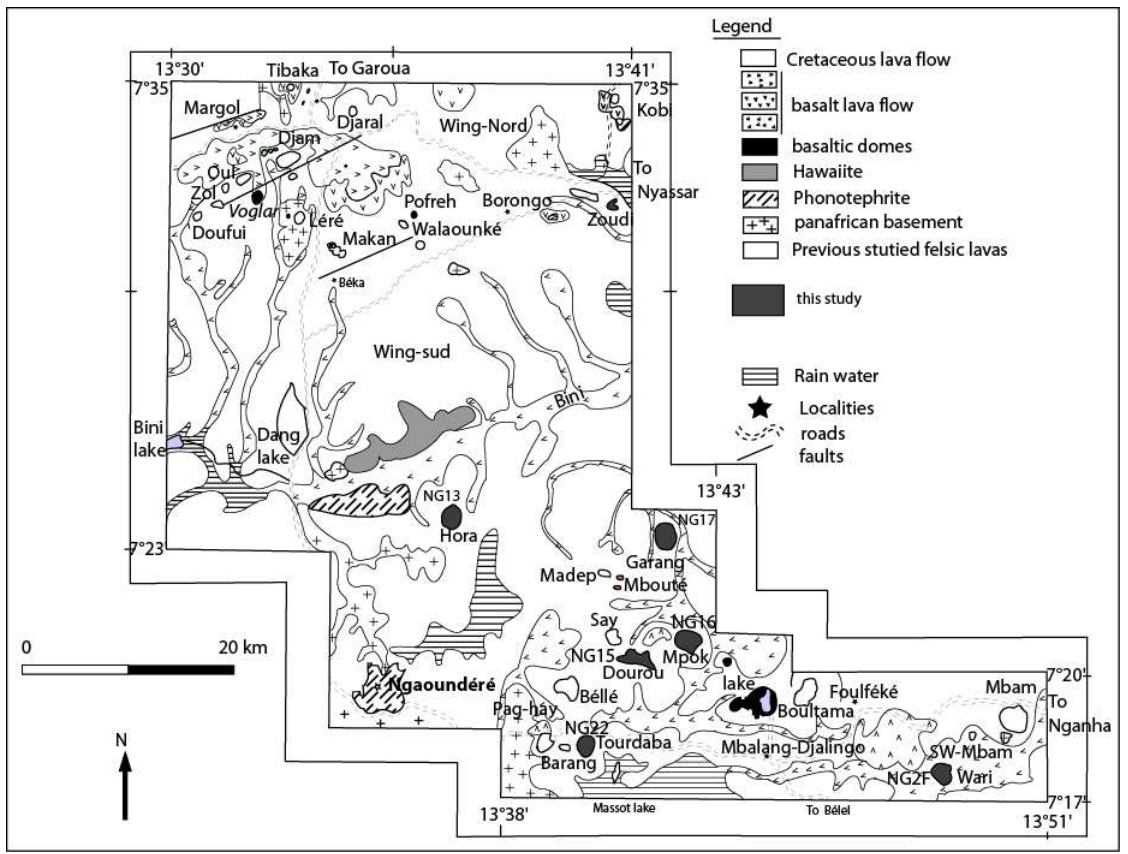

Figure 2: Geological sketch map of studied area after Nkouandou et al. (2010), modified.

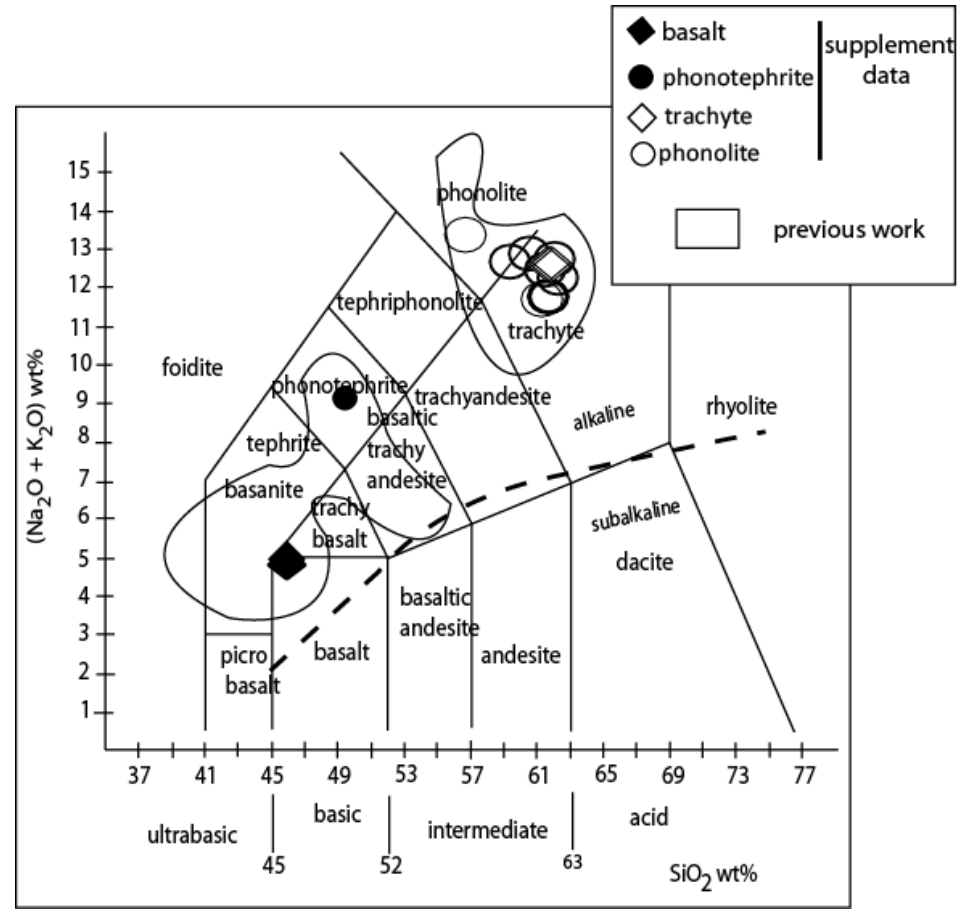

Figure 3: Chemical classification of volcanic rocks using TAS (total alkali-silica) diagram after Le Maître (2002). Dashed line separates alkaline from subalkaline fields according to Miyashiro (1978). 


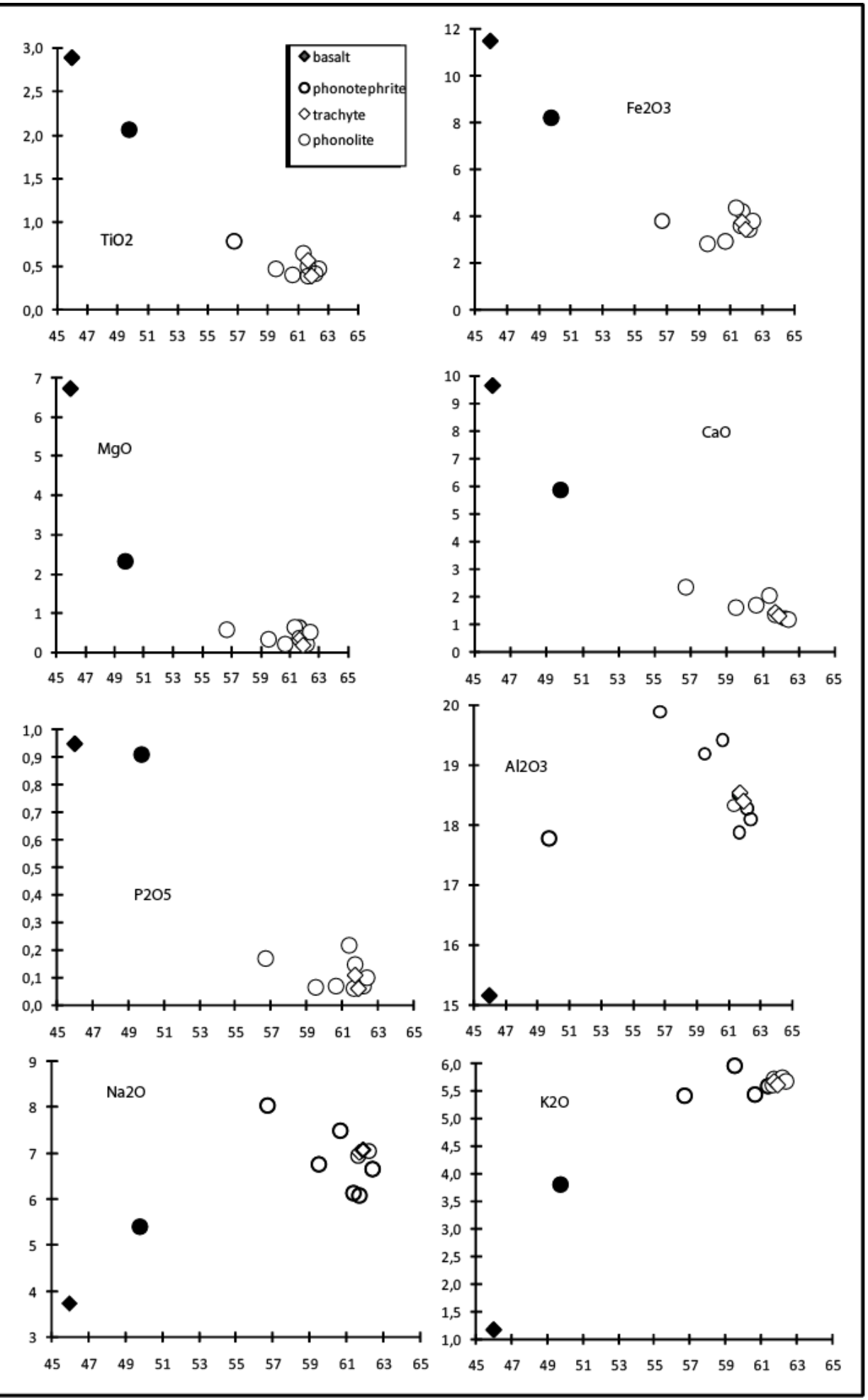

Figure 4: Major-element vs $\mathrm{SiO} 2$ distribution of the Ngaoundéré Miocene lava series. 

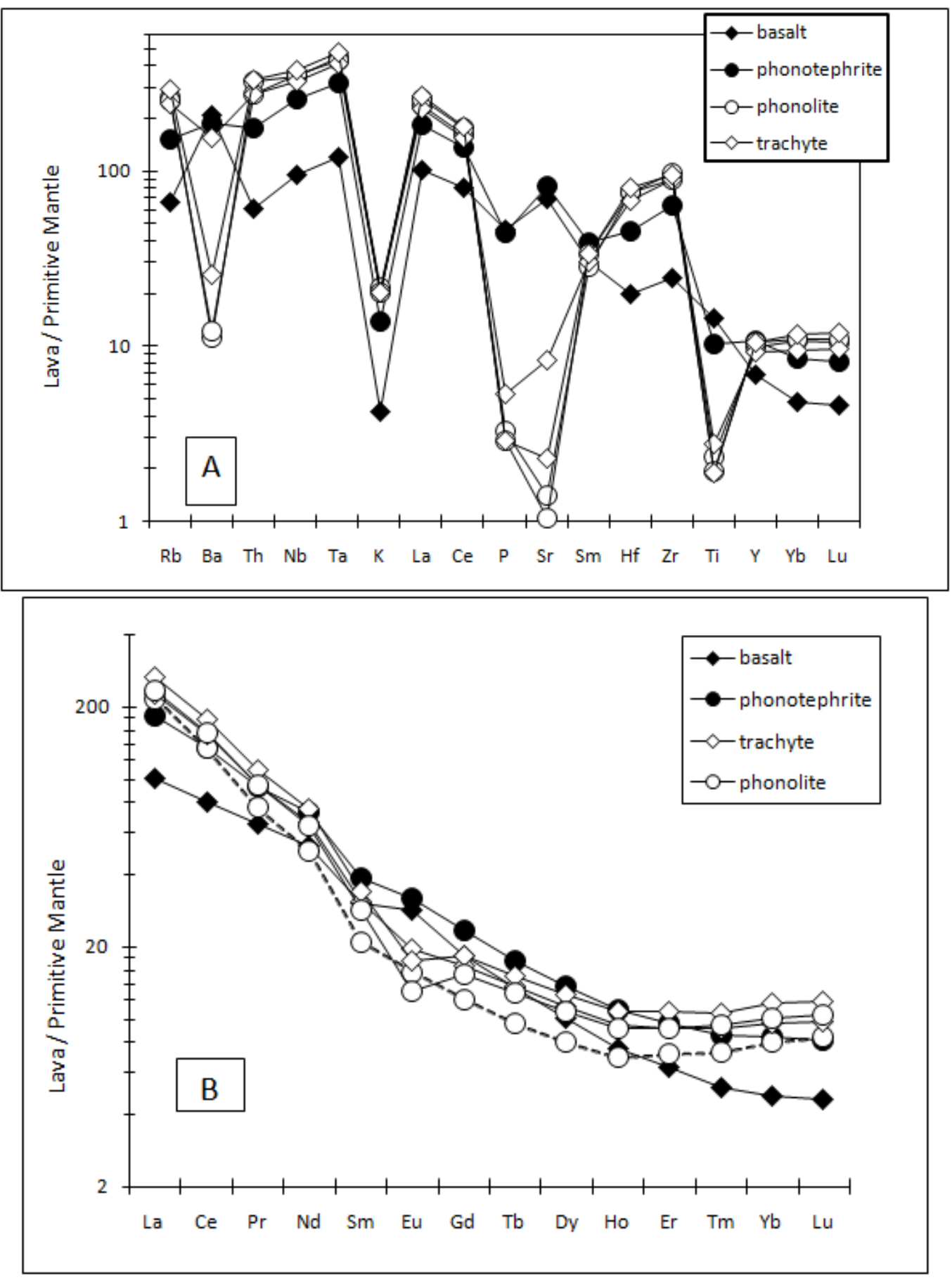

Figure 5: Primitive mantle-normalized traces elements (A) REE (B) for basaltics and felsics of Miocene volcanic lavas of Ngaoundéré. Data source for normalization are taken from Hofmann (1988). 


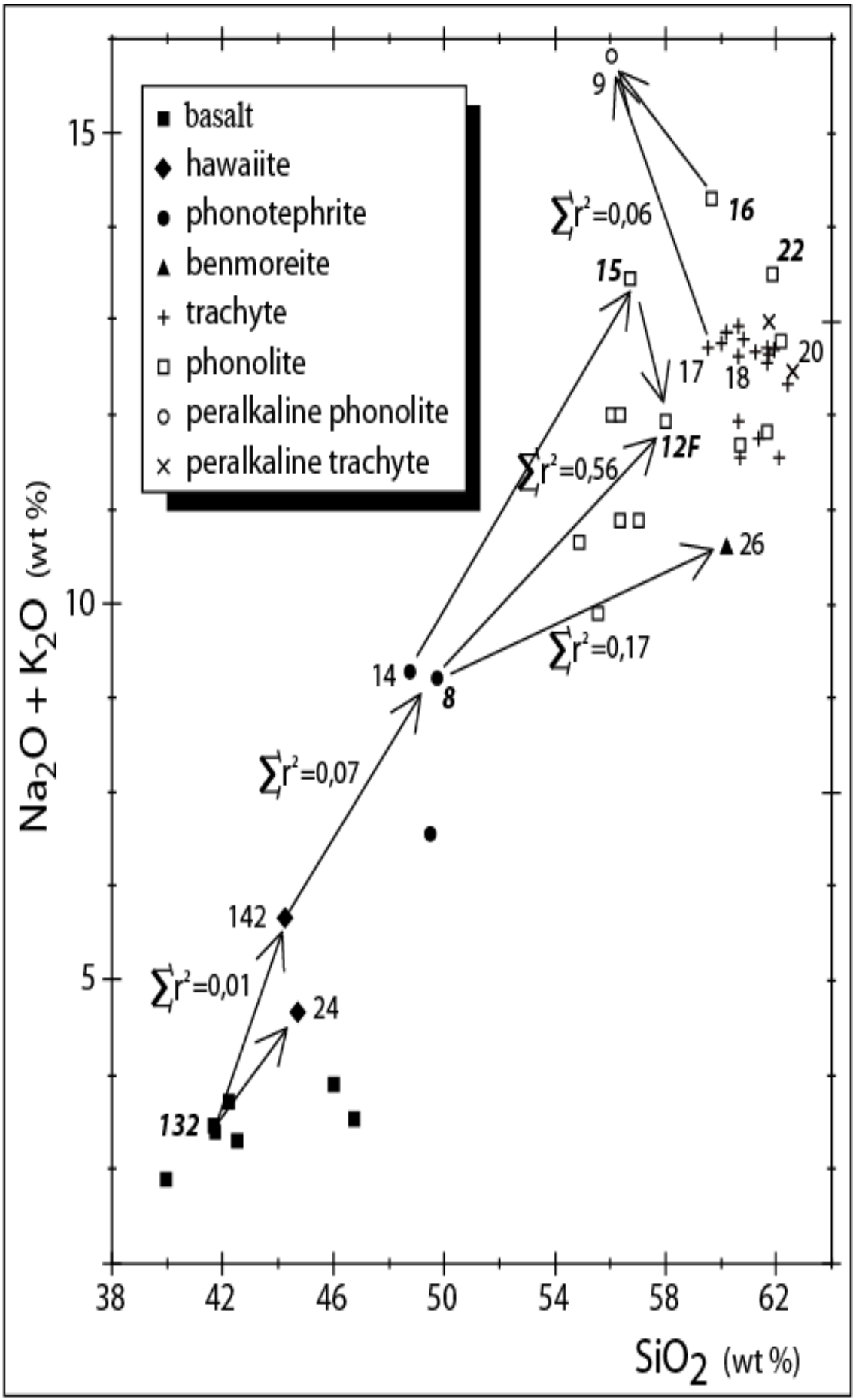

Figure 6: Modeling of the differentiation by fractional crystallization by major-element data in the least square mass balance using the compositions of the minerals phases previously analyzed by electron microprobe. Bold-italic numbers are those of sample used in this study $\sum r^{2}$ : sum of the square residue. Numbers in bold represent are those of the samples used in the model. 


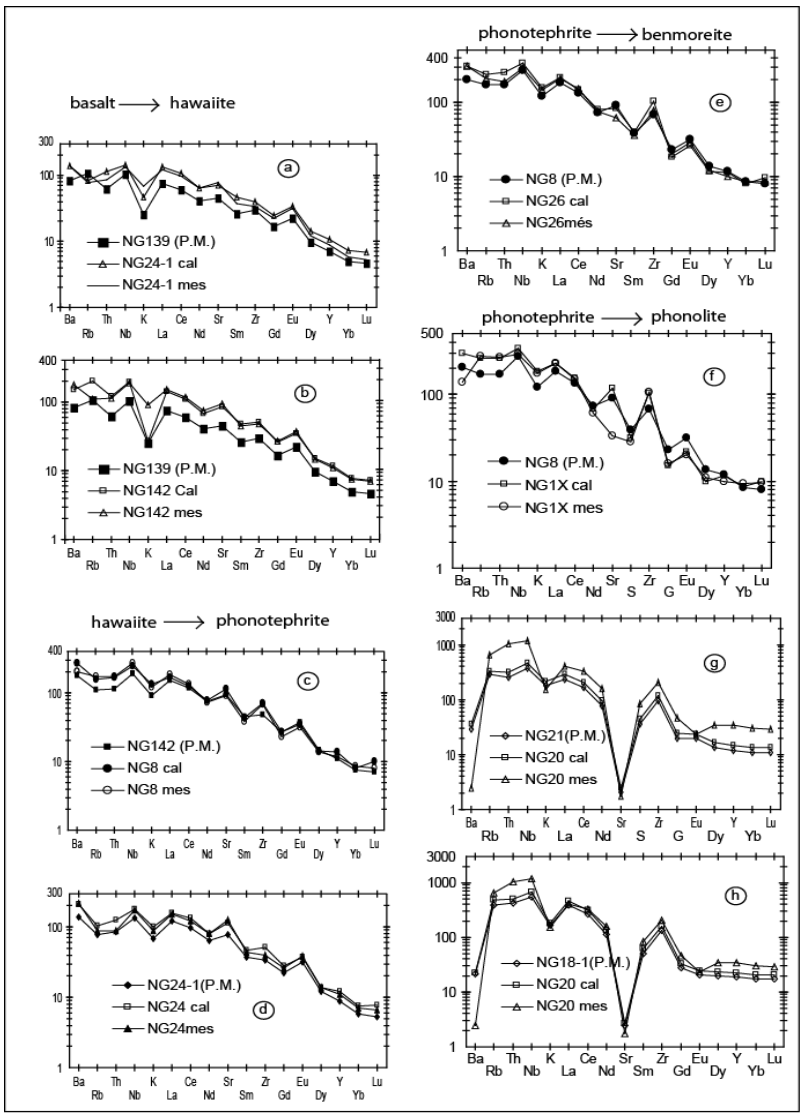

Figure 7: Tests of closed-system fractional crystallization used for the genesis of Ngaoundéré. Miocene lavas: (a) and (b) from basalt to hawaiite, (c) and (d) from hawaiite to phonotephrite, (e) from phonotephrite to benmoreite and (f) phonolite, (g) and (h) from phonolite to trachyte. Primitive mantle-normalized data are from Hofmann (1988) trace elemnt patterns of calculated daughter (cal) liquids and analysed parental (P.M.) and daughter liquids (mes) for each test are indicated. Cal: calculated, mes: mesured

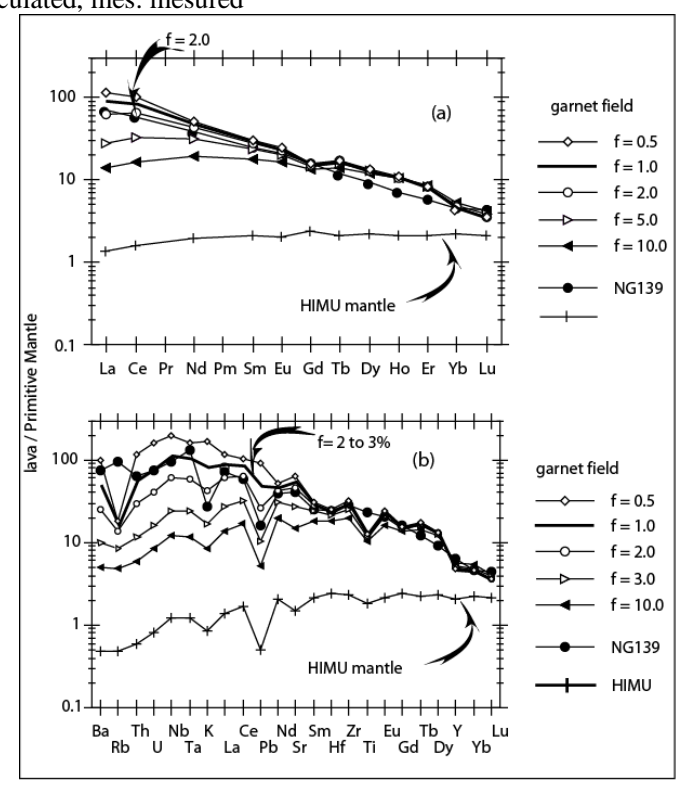

Figure 8: Partial melting rate of the Ngaoundéré Miocene volcanism modeling by REE (a) and trace element (b). HIMU mantle normalized data are taken from Hofmann (1988). 
O. F. NKOUANDOU et al. / Int. J. Biol. Chem. Sci. 10(4): 1903-1917, 2016

Table 1: Whole rocks chemical analyses and CIPW norm of Ngaoundéré lavas.

\begin{tabular}{|c|c|c|c|c|c|c|c|c|c|c|c|c|}
\hline rock & basanite & phonotephrite & phonolite & & & & & & & & trachyte & \\
\hline sample & NG132 & NG 8 & NG 12-2 & NG15 & NG16 & NG22 & NG12 & $\mathrm{NG} 2 \mathrm{~F}$ & NG23 & NG21 & NG17 & NG13 \\
\hline $\mathrm{SiO}_{2}(\mathrm{wt} \%)$ & 45.98 & 49.74 & 56.71 & 61.69 & 62.18 & 61.35 & 59.50 & 60.64 & 61.64 & 62.39 & 61.68 & 61.89 \\
\hline $\mathrm{Al}_{2} \mathrm{O}_{3}$ & 15.15 & 17.78 & 19.88 & 17.87 & 18.27 & 18.32 & 19.17 & 19.41 & 18.50 & 18.09 & 18.53 & 18.39 \\
\hline $\mathrm{Fe} 2 \mathrm{O} 3$ & 11.51 & 8.22 & 3.77 & 4.20 & 3.45 & 4.36 & 2.83 & 2.92 & 3.58 & 3.79 & 3.72 & 3.41 \\
\hline $\mathrm{CaO}$ & 9.63 & 5.88 & 2.36 & 1.38 & 1.21 & 2.02 & 1.59 & 1.67 & 1.33 & 1.19 & 1.41 & 1.31 \\
\hline $\mathrm{Na}_{2} \mathrm{O}$ & 3.74 & 5.40 & 8.04 & 6.09 & 7.04 & 6.15 & 6.76 & 7.50 & 6.94 & 6.66 & 7.03 & 7.07 \\
\hline $\mathrm{K}_{2} \mathrm{O}$ & 1.17 & 3.81 & 5.42 & 5.73 & 5.75 & 5.60 & 5.96 & 5.44 & 5.62 & 5.68 & 5.68 & 5.62 \\
\hline $\mathrm{P}_{2} \mathrm{O}_{5}$ & 0.95 & 0.91 & 0.17 & 0.15 & 0.07 & 0.22 & 0.07 & 0.07 & 0.06 & 0.10 & 0.11 & 0.06 \\
\hline LOI & 2.17 & 2.25 & 0.66 & 1.05 & 0.66 & 0.85 & 2.62 & 1.41 & 1.25 & 1.31 & 0.70 & 1.23 \\
\hline $\mathrm{Sr}$ & 1381 & 1634 & 1421 & 54.96 & 22.29 & 215.2 & 27.88 & 406.5 & 20.63 & 37.51 & 164 & 45.48 \\
\hline Cs & 0.318 & 1.094 & 1.014 & 0.638 & 1.528 & 0.715 & 1.586 & 1.165 & 0.778 & 1.347 & 1.179 & 1.533 \\
\hline $\mathrm{Ba}$ & 1369 & 1241 & 2058 & 274.8 & 123.1 & 913.8 & 74.03 & 1498 & 80.32 & 176.2 & 1025 & 168.3 \\
\hline V & 201.3 & 83.57 & 15.93 & 1.941 & & 5.247 & 8.21 & 3.782 & & & 4.549 & \\
\hline $\mathrm{Cr}$ & 166.5 & & & & & & < L.D. & & & & & \\
\hline Co & 36.13 & 12.38 & 0.843 & 0.701 & 0.487 & 1.363 & 0.306 & 0.37 & 0.386 & 0.252 & 0.938 & 0.479 \\
\hline $\mathrm{Ni}$ & 73.04 & & & & & & < L.D. & & & & & \\
\hline $\mathrm{Cu}$ & 36.7 & 6.912 & 6.143 & 8.319 & & 4.436 & < L.D. & & & & & \\
\hline
\end{tabular}


O. F. NKOUANDOU et al. / Int. J. Biol. Chem. Sci. 10(4): 1903-1917, 2016

\begin{tabular}{|c|c|c|c|c|c|c|c|c|c|c|c|c|}
\hline $\mathrm{Zn}$ & 130.7 & 172.9 & 170.1 & 150.1 & 152 & 146.6 & 159 & 158.1 & 174.4 & 178.6 & 152.7 & 170.8 \\
\hline$Y$ & 29.73 & 46.42 & 48.88 & 32.14 & 38.96 & 31.11 & 42.25 & 31.53 & 44.84 & 46.92 & 39.63 & 45.52 \\
\hline $\mathrm{Zr}$ & 255.8 & 666.5 & 841.6 & 887.9 & 979.1 & 775.9 & 1025 & 946.2 & 935.8 & 945.9 & 938.8 & 995 \\
\hline $\mathrm{Hf}$ & 5.675 & 12.75 & 15.68 & 17.11 & 22.9 & 14.82 & 21.56 & 16.92 & 21.51 & 20.69 & 19.04 & 22.9 \\
\hline $\mathrm{Ta}$ & 4.427 & 11.76 & 17.92 & 12.08 & 15.52 & 11.02 & 16.72 & 9.655 & 15.9 & 15.36 & 15.25 & 17.73 \\
\hline Th & 4.835 & 13.96 & 16.28 & 15.72 & 26.21 & 14.46 & 25.67 & 21.35 & 22.01 & 21.01 & 22.05 & 26.45 \\
\hline $\mathrm{La}$ & 62.18 & 113.1 & 149.7 & 116.4 & 144.3 & 112.3 & 147 & 133.2 & 158.1 & 145.9 & 138.8 & 163.6 \\
\hline $\mathrm{Ce}$ & 128.2 & 216.4 & 279 & 208.1 & 251.3 & 202.8 & 256.9 & 214.8 & 282.2 & 266.9 & 246.8 & 286.3 \\
\hline $\operatorname{Pr}$ & 15.74 & 22.3 & 27.42 & 19.58 & 22.86 & 20.91 & 26.37 & 18.37 & 26.37 & 25.76 & 22.99 & 26.32 \\
\hline $\mathrm{Nd}$ & 62.91 & 87.1 & 98.52 & 67.28 & 75.63 & 68.29 & 75.88 & 59.53 & 88.98 & 90.5 & 78.88 & 88.7 \\
\hline $\mathrm{Sm}$ & 11.74 & 14.98 & 15.41 & 10.16 & 10.95 & 10.33 & 10.98 & 8.072 & 13.05 & 14.04 & 11.84 & 13.15 \\
\hline $\mathrm{Eu}$ & 4.123 & 4.637 & 4.638 & 2.25 & 1.912 & 2.683 & 2.293 & 2.269 & 2.507 & 2.94 & 2.853 & 2.536 \\
\hline Ho & 1.074 & 1.544 & 1.66 & 1.086 & 1.303 & 1.054 & 1.393 & 0.981 & 1.486 & 1.572 & 1.339 & 1.515 \\
\hline $\mathrm{Er}$ & 2.623 & 4.02 & 4.522 & 3.131 & 3.791 & 2.984 & 4.077 & 2.964 & 4.277 & 4.461 & 3.784 & 4.47 \\
\hline $\mathrm{Tm}$ & 0.332 & 0.551 & 0.655 & 0.475 & 0.603 & 0.449 & 0.633 & 0.466 & 0.657 & 0.686 & 0.584 & 0.68 \\
\hline $\mathrm{Yb}$ & 1.988 & 3.512 & 4.108 & 3.295 & 4.167 & 3.059 & 4.409 & 3.311 & 4.51 & 4.589 & 3.94 & 4.794 \\
\hline $\mathrm{Lu}$ & 0.292 & 0.517 & 0.603 & 0.525 & 0.659 & 0.474 & 0.674 & 0.532 & 0.699 & 0.708 & 0.617 & 0.756 \\
\hline $\mathrm{Ce} / \mathrm{Yb}$ & 16.69 & 15.95 & 17.58 & 16.35 & 15.61 & 17.16 & 15.08 & 16.79 & 16.20 & 15.05 & 16.21 & 15.46 \\
\hline
\end{tabular}


O. F. NKOUANDOU et al. / Int. J. Biol. Chem. Sci. 10(4): 1903-1917, 2016

Table 2: Result of least square mass balance using the compositions of the minerals phases previously analyzed by electron microprobe.

\begin{tabular}{|c|c|c|c|c|c|c|c|c|c|c|c|c|c|}
\hline \multicolumn{14}{|l|}{ lava } \\
\hline R.M & R.D & $\mathbf{F}$ & Ol & Cpx & Hbl & PI & K-felds & $\mathbf{O x}$ & Ap & Ti & На & $\begin{array}{l}\text { R.D. } \\
\text { recalculated }\end{array}$ & Sum $\mathbf{R} * \mathbf{R}$ \\
\hline NG142 & NG24-1 & 52 & 5 & 19 & 0 & 17 & 0 & 7 & 0 & 0 & 0 & NG142' & 0,084 \\
\hline NG20 & NG9 & 32,9 & 0 & 12 & 0 & 0 & 55,1 & 0 & 0 & 0 & 0 & NG9' & 0,105 \\
\hline NG26 & NG20 & 78,9 & 0 & 8,3 & 0 & 0 & 12 & 0,8 & 0 & 0 & 0 & NG20' & 0,168 \\
\hline NG24 & $\mathrm{NG} 24$ & 65,9 & 4,7 & 12 & 0 & 9 & 0 & 5,8 & 2,7 & 0 & 0 & NG24' & 0,411 \\
\hline NG11 & NG9 & 59,7 & 0 & 0 & 0 & 0 & 39 & 12 & 0 & 0,1 & 0 & NG9' & 0,063 \\
\hline NG15 & NG1Q & 77 & 0 & 8 & 0 & 0 & 6 & 1 & 0 & 0 & 8 & NG1Q' & 0,059 \\
\hline NG8 & NG5 & 77,9 & 0 & 4,9 & 8,6 & 1,9 & 0 & 4,6 & 2,1 & 0 & 0 & NG5é & 0,0291 \\
\hline NG8 & NG1X & 64,2 & 0 & 0,8 & 20 & 9,1 & 0 & 3,2 & 2,7 & 0 & 0 & NG1X' & 0,561 \\
\hline NG25 & NG20 & 84 & 0 & 1 & 0 & 0 & 15 & 0 & 0 & 0 & 0 & NG20' & 0,1858 \\
\hline NG17 & NG20 & 82,8 & 0 & 1 & 0 & 0 & 16 & 0,2 & 0 & 0 & 0 & NG20' & 0,3088 \\
\hline
\end{tabular}

R.M.: rock mother; rock daughter; F: melt fraction; Ol: olivine; Cpx: clinopyroxene; Hbl: hornblende; Pl: plagioclase; K-felds: potassic feldspar; ox: oxides; Ap: apatite; Sph: Ti: titanite; Ha: hayune; Rock daughter; Sum R*R: sum of the least square. 


\section{DISCUSSION}

Fractional crystallization modeling

Considering major elements, decrease of $\mathrm{MgO}, \mathrm{Fe}_{2} \mathrm{O}_{3}, \mathrm{TiO}_{2}$ and $\mathrm{CaO}$ contents with increasing $\mathrm{SiO}_{2}$ contents (Figure 5) suggest fractionation of olivine, clinopyroxene and $\mathrm{Fe}$ Ti-oxides in a parental basaltic magma. Decrease in $\mathrm{Al}_{2} \mathrm{O}_{3}, \mathrm{Na}_{2} \mathrm{O}$ and $\mathrm{K}_{2} \mathrm{O}$ in felsic lavas results from feldspar fractionation and decrease in $\mathrm{P}_{2} \mathrm{O}_{5}$ corresponds to apatite fractionation.

Fractional Crystallization modeling with major elements distribution by massbalance crystal fractionation has been attempted by Nkouandou et al. (2008) and Nkouandou et al. (2010) by using the compositions of the mineral phases present as phenocrysts in the lavas. This model is reexamined in this work where calculated chemical compositions of lavas and proportions of removed mineral phases during differentiation of the magmas were determined using mass-balance computation minimizing the sum of squares of residuals. The result of this modeling from basalts to evolved felsic lavas follows the differentiation evolution as indicated in Figure 6 and results are recorded in Table 2.

Trace elements' modeling of closedsystem Assimilation and Fractional Crystallization (AFC) has also been attempted in this study, using bulk distribution coefficient values from the literature ( Blundy and Wood, 2003) and mineral proportions as previously determined in major element modeling (Table 2), using equation (1).

$$
\mathrm{C}_{1}^{\mathrm{i}}=\mathrm{C}_{\mathrm{o}}^{\mathrm{i}} \mathrm{F}^{(\mathrm{Di}-1)}(1)
$$

$\mathrm{C}^{\mathrm{i}}$ is the concentration of element " $\mathrm{i}$ " in calculated liquid "l"; $\mathrm{C}_{\mathrm{O}} \mathrm{i}$ is the concentration element " $\mathrm{i}$ " in the parental magma; $\mathrm{F}$ is the proportion of fractionated parental liquid and Di, the distribution coefficient of element " $i$ ". $\mathrm{Kd}$ used for the calculation of distribution coefficients Di used in this model are taken from Blundy and Wood (2003). Data used here integrate the previous (Nkouandou et al., 2018, 2010) and newly analyses (Table 1).
Results of detail modeling illustrated here (Figure 7) are consistent with a differentiation of the whole lava series dominated by AFC. It occurred that modeling using such an AFC process failed for tentative derivation of some phonolites and trachytes from any proposed parental felsic lavas of the series.

\section{Partial melting rate determination}

Determination of partial melting rate for Ngaoundéré volcanism is revisited here, using the method of fractional melting based on the mean of integration between 0 and $\mathrm{F}$ (melting interval) proposed by Shaw (1970) :

$$
\mathrm{C}_{\text {pooled }}^{\mathrm{i}}=\mathrm{C}_{\mathrm{o}}^{\mathrm{i}} / \mathrm{F}\left[1-\left(1-\mathrm{FP}_{\mathrm{i}} / \mathrm{D}_{\mathrm{i}}\right)^{1 / \mathrm{Pi}}\right](2)
$$

$\mathrm{C}_{\text {pooled }}^{\mathrm{i}}$ represents the mean of integration between 0 and $\mathrm{F}$ of fractions infinitesimals of produced liquids, Cio is the concentration of element " $\mathrm{i}$ " in the source, $\mathrm{F}$ is the rate of partial melting, $\mathrm{Di}$ is the distribution coefficient and $\mathrm{Pi}$ the coefficient of mineral proportion entering the liquid. For $\mathrm{Di}$ and $\mathrm{Pi}$ calculation, partitions coefficients $\mathrm{Kd}$ for different minerals are the same used in the previous models. Numerous compositions of multi-component mantle sources have been proposed for alkaline lava series worldwide (Stracke et al., 2005). Following the models proposed for the genesis of the magma sources of French Polynesia (Clouard et al., 2000) lava series, we propose three compositions of different mantle sources for this model: (1) High $\mu$ (HIMU) type mantle source composed of $18 \%$ Mid-Ocean Ridge Basalts (MORB) and $81 \%$ depleted mantle with the small amount of pelagic sediment (1\%) and phlogopite residue in the garnet stability field, (2) depleted mantle in the spinel stability field and (3) depleted mantle in the garnet stability field (Nkouandou, 2006 for more details). The different mineralogical mantle modes used in the model are from Johnson et al. (1990). The results show that only mantle source of HIMU type component in the garnet stability field matches with the compositions of the Ngaoundéré parental basalt. The results are shown in Figure 8 as multielement and REE normalized (to 
Hofmann, 1988) pattern compared to the Ngaoundéré parental basalts (NG132, NG121) and the calculated daughter liquid patterns. The multielement patterns (Figure $8 \mathrm{a}$ ) of the calculated daughter liquids match with $2 \%$ melt fraction. In REE element diagram (Figure 8b), the 3\% melt fraction match with the NG132 and NG121 of Ngaoundéré basalt. The presence of garnet suggests the approximate depth of $80 \mathrm{~km}$ for Ngaoundéré mantle source. Keliphite garnet found in the pyroclastite of Youkou region $(05 \mathrm{~km}$ far from Ngaoundéré) (Temdjim, 2005) enhances this suggestion. By now, our model suggests that the Ngaoundéré parental magma basalt have been probably produced by the degree of melting of 2 to $3 \%$ of the peridotitic mantle which composition is similar to that of HIMU component $(18 \% \mathrm{MORB}+81 \% \mathrm{DM}+1 \%$ pelagic sediment + residual phlogopite) in the garnet stability field at the depth of nearly 80 $\mathrm{km}$. The low partial melting rate is consistent with the high $(\mathrm{Ce} / \mathrm{Yb})_{\mathrm{N}}$ ratios $(15.0-18.0)$ and which is similar to those calculated for the continental and oceanic sectors of the Cameroon Volcanic Line (CVL): 12 < $(\mathrm{Ce} / \mathrm{Yb})_{\mathrm{N}}<22$ (Ngounouno et al., 2006 ; Kamgan et al., 2010). These results are strongly supported by the recent geochemical modeling proposed by Asaah et al. (2015) for the whole CVL volcanism.

\section{Conclusion}

Ngaoundéré Cenozoic volcanism is consistent with a cogenetic alkaline lava series. Geochemistry and detail modeling of petrogenetic processes of the composition of the parental magmas for the whole series is consistent with parental magmas undergo crystal fractionation of olivine, $\mathrm{Fe}$ - Ti oxides, clinopyroxene ( \pm plagioclase $)$, producing magmas of phonotephrite composition. Felsic lavas have been produced by the fractionation of K-feldspar, clinopyroxene, amphibole, biotite, Fe-Ti oxides, nosean, nepheline and aenigmatite. All lavas have been preserved from crustal contamination. Thus, Adamawa felsic lavas are not the result of continuous crustal contamination as previously suggested for some felsic lavas of continental sector of Cameroon Volcanic Line. The best fit for the calculated composition of the magma source of Ngaoundéré basaltic lavas is the combination of $18 \% \mathrm{DM}+81 \% \mathrm{MORB}+1 \%$ + of pelagic sediment $+1 \%$ phlogopite phase. The partial melting rate of 2 to $3 \mathrm{wt} \%$, contrary to 1 to $2 \%$ partial melting previously proposed, is at the origin of Ngaoundéré parental basalt. The composition of this source is slightly different from that of CVL.

\section{COMPETING INTERESTS}

The authors declare that they have no competing interests

\section{AUTHORS'CONTRIBUTIONS}

OFN carried out the field work, conception, modeling and writing; AFM did the supplement analyses by financial support trough AUF grants; BD supervised the work.

\section{ACKNOWLEDGEMENTS}

Authors thank Mrs. Valérie of the 'Laboratoire des lames minces' of the department of Earth Sciences of the University of Paris-Saclay for technical assistance during thin section production and the personnel of Acmel Laboratory for chemical analyses. Mrs Thi Kim Ngan Ho is also thanked for administration facilities.

\section{REFERENCES}

Asaah ANE, Yokoyama T, Aka FT, Usui T, Wirmvem MJ, Tchamabe BC, Ohba T, Tanyileke G, Hell JV. 2015. A comparative review of petrogenetic processes beneath the Cameroon Volcanic Line: Geochemical constraints. Geoscience Frontiers, 6: 557-570.

Doi:10.1016/j.gsf.2014.04.012

Blundy J, Wood B. 2003. Partitioning of trace elements between crystals and melts Earth and melts. Planetary Science Letters, 210: 383-397. doi:10.1016/S0012-821X(03)00129-8

Clouard V, Bonneville A, Barsczus HG. 2000. Size and depth of ancient magma 
reservoirs under atolls and islands of French Polynesia using gravity data. Journal of Geophysical Research, 105 (B4): 8173-8191.

doi:10.1029/1999JB900393

Déruelle B, Ngounouno I, Demaiffe D. 2007. The 'Cameroon Hot Line' (CHL): a unique example of active alkaline intraplate structure in both oceanic and continental lithospheres. C.R. Geoscience, 339: 589-600. Doi:10.1016/j.crte.2007.07.007

Fagny AM, Nkouandou OF, Déruelle B, Ngounouno I. 2012. Revised petrology and new chronological data on the peralkaline felsic lavas of Ngaoundéré volcanism (Adamawa plateau, Cameroon, Central Africa): evidence of open-system magmatic processes. Analele Stiintifice ale Universitatii "Al. I. Cuza” din Iasi Seria Geologie, 58: 522.

Ganwa AA, Klotzli US, Hauzenberger C. 2016. Evidence for Archean inheritance in the pre-Panafrican crust of Central Cameroon: Insight from zircon internal structure and LA-MCICP-MS UePb ages. Journal of African Earth Sciences, 120: $12-22$.

Doi.org/10.1016/j.jafrearsci.2016.04.013

Ganwa AA, Siebel W, Frisch W, Shang CK, Ekodeck, GE. 2011b. Geochemistry and geochronology of the Méiganga metadiorite: implications on the timing of D2 deformational phase in Adamawa Yadé Domain in Cameroon. Int. J. Biol. Chem. Sci., 5(4): 1754-1767. DOI : http://dx.doi.org/10.4314/ijbcs.v5i4.37

Ganwa AA, Wolfgang S, Cosmas SK, Naimou S, Ekodeck GE. 2011a. New Constraints from $\mathrm{Pb}$-Evaporation Zircon Ages of the Méiganga AmphiboleBiotite Gneiss, Central Cameroon on Proterozoic Crustal Evolution. International Journal of Geosciences, 2:138-147. Doi:10.4236/ijg.2011.22014

Hofmann AW. 1988. Chemical differentiation of the Earth: the relationship between mantle, continental crust, and oceanic crust. Earth Planet Sci. Lett., 90: 297314.

Johnson KTM, Dick HJB, Shimuzu N. 1990. Melting in the oceanic upper mantle: an ion microprobe study of diopsides in abyssal peridotites. J. Geophy. Res., 95 (B3): 2661-2678. DOI: 10.1029/JB095iB03p02661

Kamgang P, Njonfang E, Nono A, Dedzo MG, Tchoua FM. 2010. Petrogenesis of a silicic magma system: Geochemical evidence from Bamenda Mountains, NW Cameroon, Cameroon Volcanic Line. J. Afr. Earth Sci., 58: 285-304. Doi:10.1016/j.jafrearsci.2010.03.008

Le Maitre RW. 2002. Igneous Rocks-A Classification and Glossary of Terms. Recommendations of the IUGS SubCommission on the Systematics of Igneous Rocks (2nd edn). Cambridge University Press: Cambridge.

Mbowou IBG, Nguihdama D, Yamgouot NF, Ntoumbe M, Ngounouno I. 2013. Tibearing aenigmatite from Djinga Tadorgal (Adamawa plateau) and Sao Tomé (Cameroon Line) phonolites: geochemical implications and application of the QUILF thermobarometer for the crystallization conditions. Int. J. Biol. Chem. Sci., 7(6): 2600-2610.

DOI: http://dx.doi.org/10.4314/ijbcs.v7i6.34

Ngounouno I, Deruelle B, Montigny R, Demaiffe D. 2006. Les camptonites du mont Cameroun, Cameroun, Afrique. $C$. $R$. Geoscience, 338: 537-544. Doi:10.1016/j.crte.2006.03.015

Nkouandou OF, Bardintzeff JM, Fagny AM. 2015b. Sub-continental lithospheric mantle structure beneath the Adamawa plateau inferred the petrology of ultramafic xenoliths from Ngaoundéré (Adamawa Plateau, Cameroon, Central Africa). Journal of African Earth Sciences, 111: 26-40. Doi:10.1016/j.jafrearsci.2015.07.004

Nkouandou OF, Fagny AM, Iancu GO, Bardintzeff J-M. 2015a. Petrology and geochemistry of doleritic dyke of Likok 
(Cameroon, central Africa). Carpathian Journal of Earth and Environmental Sciences, 10: 121-132. DOI: https://www.researchgate.net/.../272070 431

Nkouandou OF, Ngounouno I, Déruelle B, Onhenstetter D, Montigny R, Demaiffe D. 2008. Petrology of the Mio-Pliocene Volcanism to the North and East of Ngaoundéré (Adamawa-Cameroon). $C$. R. Geoscience, 340: 28-37. Doi:10.1016/j.crte.2007.10.012

Nkouandou OF, Ngounouno I, Déruelle B. 2010. Geochemistry of recent basaltic lavas from the north and east of Ngaoundéré zones (Cameroon, Adamawa Plateau, Central Africa): petrogenesis and the nature of the source. Int. J. Biol. Chem. Sci., 4: 9841003.

DOI: http://dx.doi.org/10.4314/ijbcs.v4i4.630 38.

Nkouandou OF. 2006. Pétrologie du volcanisme au nord et à l'est de Ngaoundéré. Thèse NR, Université Pierre et Marie Curie (Paris-6), Paris, p. 120.

Nnange JM, NgakoV, Fairhead JD, Ebinger CJ. 2000. Depths to density discontinuities beneath the Adamawa Plateau region, Central Africa, from spectral analyses of new and existing gravity data. Journal of African Earth Sciences, 30: 887-901. Doi: 10.1016/S0899-5362(00)00058-0

Nnange JM, Poudjom Djomani YH, Fairhead JD, Ebinger C. 2001. Determination of the isostatic compensatiom mechanism of the region of the Adamawa dome, West Central Africa using the admittance technique of gravity data. African Journal of Science and Technology (AJST) Science and Engineering, 1: 29-35.

Pouchou JL, Pichoir F. 1991. Quantitative analysis of homogeneous or stratified microvolumes applying the model "PAP". In Electron Probe Quantification, Heinriche DE (ed). Plenum Press: New York; 31-75.

Shaw DM. 1970. Trace element fractionation during anatexis. Geochim. Cosmochim. Acta, 34: 237-243.

Stracke A, Hofmann AW, Hart RS. 2005. HIMU and the rest of the mantle zoo. Geochem. Geophys. Geosyst., 6: 1-20. DOI: $10.1029 / 2004 \mathrm{GC} 000824$

Tchameni R, Pouclet A, Penaye J, Ganwa AA, Toteu SF. 2006. Petrography and geochemistry of the Ngaoundéré PanAfrican granitoids in Central North Cameroon: implications for their sources and geological setting. J. Afr. Earth Sci., 44: 511-529. Doi: 10.1016/j.jafrearsci.2005.11.017

Temdjim R. 2005. Contribution à la connaissance du manteau supérieur du Cameroun au travers de l'étude des enclaves ultrabasiques et basiques remontées par les volcans de Youkou (Adamaoua) et de Nyos (Ligne du Cameroun). Thèse Doctorat État, Université de Yaoundé 1, Yaoundé, p. 339.

Toteu SF, Penaye J, Poudjom Djomani Y. 2004. Geodynamic evolution of the Pan-African belt in central Africa with special reference to Cameroon1. Can. J. Earth Sci., 41: 73-85. Doi: 10.1139/E03-079 